\title{
歩行トリップ長の研究
}

\section{A STUDY ON WALKING TRIP LENGTH}

\author{
村田 隆 裕*
}

By Takahiro MURATA

\section{1.はじめに}

この論文の目的は, 都市の中心部における歩行者の歩 行距離の統計的分析から, 歩行距離の理論分布を導き, そのパラメーターについて比較考察を行って, トリップ 長分布一般について理論的説明を試みるとともに，交通 施設計画のための基礎資料を得ようとするものである.

\section{2. 歩行距離に関する諸值}

アメリカおよびわが国で得られている歩行距離の中央 值 (50 パーセンタイル值) と 95 パーセンタイル值を, 歩行を始めた施設別, およびトリップ目的別にみると, 表一1, 表一2 のようになっている.

西ドイツ, カールスルーエの調査では, 駐車場から目 的地点までが 200 300 $\mathrm{m}$ になると利用頻度が急激に低 下することが知られ, また, デンマークのアールボルグ,

表一1 起点となる交通施設別歩行トリップ長

(単位 : m)

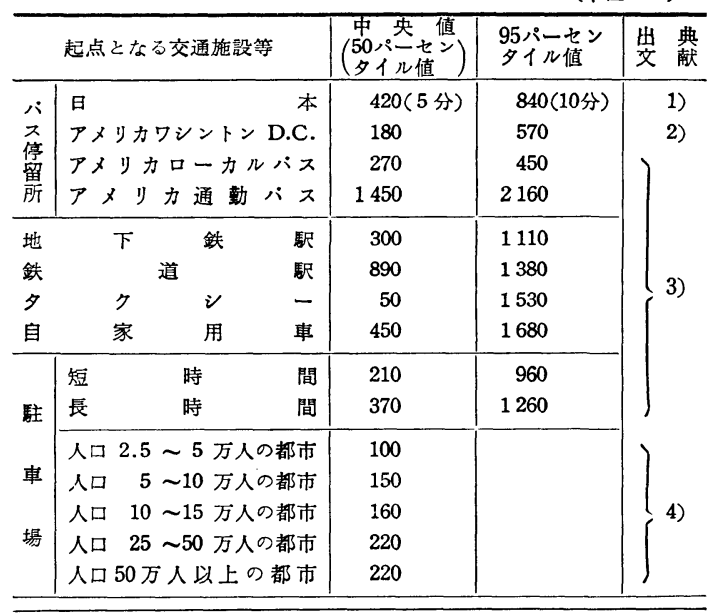

* 正会員 工博 科学警察研究所交通安全研究室主任研究官

\begin{tabular}{|c|c|c|c|c|}
\hline \multicolumn{4}{|c|}{ 表-2 } & (単位 : m) \\
\hline 的 & 中央值 $\left(\begin{array}{c}50 \\
\text { 夕 }\end{array}\right.$ & パーセン & $\begin{array}{l}\text { 95パーセン } \\
\text { タイル值 }\end{array}$ & 備 考 \\
\hline 通 & 340 & 280 & 1800 & \\
\hline 業 & 420 & 280 & 3090 & \\
\hline 個人的業務 & & 280 & & \\
\hline 宅 & & 320 & & \\
\hline 物 & 380 & 260 & 1200 & \\
\hline レクリエーンョン & 340 & $230^{*}$ & 1380 & *社交を含む \\
\hline 食 & & & 750 & \\
\hline 出 & $\begin{array}{c}\text { アメリカ } \\
(3)\end{array}$ & $\begin{array}{c}\text { アメリカ } \\
(5)\end{array}$ & & \\
\hline
\end{tabular}

ランデルス，ホルステブロにおけるバス停留所と歩行者 区域内の最重要地点との距離関する調查では, 平均 $200 \mathrm{~m}$ といら結果が得られている6).

また, 都心地区における歩行者の歩行トリップ長の平 均值は, 西ドイッのデュッセルドルフとエッセンにおけ る調査では, 自家用車を用いた 来街者はそれぞれ 1050 $\mathrm{m}, 725 \mathrm{~m}$ であり，公共輸送機関を用いた来街者はそれ ぞれ $1725 \mathrm{~m}, 1625 \mathrm{~m}$ で, いずれの都市でも後者が長 いという結果が報告されている7)・オランダ各都市の調 查では, アイントホーヘン市では自宅から徒歩で都心 買物に行く場合, 平均歩行距離は約 $800 \mathrm{~m}$, ユトレヒ ト市では自宅から大デパートまでの平均歩行距離は, 直線距離で約 $950 \mathrm{~m}$, ハーグ市では同じく $800 \mathrm{~m}$ であ $3^{8)}$.

これらの調査結果は, 各都市の交通施設配置の基準と なる数值を定めるために役立てられている.ヨーロッパ 諸国で採用されている公共輸送機関の停留所からの歩行 による到達距離として推奖されている值は $250 \mathrm{~m}$ から $1000 \mathrm{~m}$ までさまざまであるが，文献 9) の著者は，3 分圈, すなわち $160 \mathrm{~m}$ を推奖している.この 3 分圈は西 ドイッ,デュッセルドルフの都心部歩行者区域における 公共輸送機関の停留所配置計画にも採用されている ${ }^{10)}$. フランスのルーアン中心部では, 駐車場を中心として半 径 $300 \mathrm{~m}$ の円を描くと都心地区がほぼカバーされるよ 
う，駐車場と公共輸送機関の停留所の配置計画が立てら れている11).

歩行距離に関する数值は以上にみるようにさまざまで あるが, この差異は, 一つには歩行トリップの定義の違 い, また, 歩行距離分布から得られるいろいろな統計量 のうち，どれをとるかによる違い，そして都市の規模に よる違いなどによるものである. 歩行距離に関するこれ らの違いを統一的に説明づけるための理論的方法を, 都 心部に抢ける歩行距離の実態調查結果の解析を通して考 察する.

\section{3. 歩行距離分布について}

\section{（1）歩行トリップとリンク}

ここでは，歩行トリップを公共輸送機関や自家用車を 降りた地点を起点とし，いくつかの地点に立寄って用件 を済ませた後, 再び交通機関に乘るまでの徒歩による道 路上の移動と定義する.ただし，鉄道駅や駐車場ではそ の出入口（駅ならば改札口）を起終点と考える.

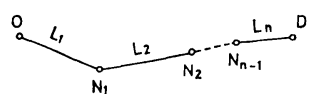

図一1＼cjkstart歩行トリップの模式図 $\left(\begin{array}{l}\mathrm{O}: \text { 起点, } \quad \mathrm{D}: \text { 終点 } \\ \mathrm{L}: \text { リンク, } \mathrm{N}: \text { 立寄地点}\end{array}\right)$
また, 起点から立寄地点 までおよび隣り合う立寄 地点間, さらに最後の立寄 地点から終点までをリンク とよぶこととする.歩行卜 リップを模式的に示すと

図一1のようになる.すなわち $n$ か所の立寄地点のある 歩行トリップは $(n+1)$ リンクから成る.

ただし, 通勤（出勤）の場合は終点は勤務先の建物の 入口とし, トリップは1リンクのみから成ると考える.

\section{（2）リンク長分布}

a）リンク長分布の仮定

このように定義した場合のリンクの長さの頻度分布が いかなるものかを考える.

歩行トリップの始点, または立寄地点からみて, 次の

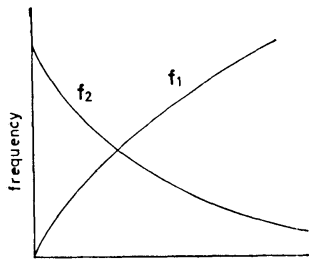

distance

図一2 潜在的目的地点の分布 $\left(f_{1}\right)$ と歩行 距離選好 の傾向 $\left(\boldsymbol{f}_{2}\right)$ 立寄地点となり得る（潜在 的な）地点は, 大量の歩行 者を誘引する施設のみがあ るような場合を除き周辺に 面的に分布していることが 一般的であろらから, 潜在 的リンク長の頻度分布は, 距離の増加に伴って増える 形になるであろう（図一2 の $\left.f_{1}\right)$. 潜在的リンク終点 数を $f_{1}$ とすると,

$$
f_{1}=c l^{\alpha}
$$

ただし，lはリンク長， $c$ とははパラメーター と表わすこととする.

一方, 歩行者の歩行距離の選好の度合いを考えると, 短距離ほど好ましく, 距離が長くなるほど嫌われる，と いう形を仮定することができる．これを負の指数関数で 代表する (図一2 の $f_{2}$ ). すなわち，

$$
f_{2}=\lambda e^{-\lambda l}
$$

入はパラメーター

と表わすこととする．このように仮定すると，現実に現 われるリンク長の頻度分布は, 式 (1)，(2) を乗じた関 数

$$
f(l)=c l^{\alpha} \cdot \lambda e^{-\lambda l}
$$

で表わされるはずである.l一確率密度関数は式 (3) に おいて,

$$
\int_{0}^{\infty} f(l) d l=1 \cdots
$$

となるよう $c$ の值を決めたものとなる.すなわち，

$$
c=\frac{\lambda^{k-1}}{\int_{0}^{\infty} z^{k-1} e^{-z} d z}=\frac{\lambda^{k-1}}{\Gamma(k)}
$$

ただし， $k=\alpha+1, \Gamma(k)$ はガンマ関数

となる.したがって

$$
f(l)=\frac{\lambda^{k} l^{k-1}}{\Gamma(k)} e^{-\lambda l}
$$

となる.これはガンマ分布であり，これをリンク長の理 論分布と仮定し得る. この関数は 2 つのパラメーター $\lambda, k$ をもち, $l$ の平均值は $m=k / \lambda$ となる.

b）リンク長分布の検証

(1) リンク長の調查

以上に述べたリンク長分布に関する仮定の検証のため に, 西ドイツにおいて実施された調査の結果を用いる. この調査は 1972 年 10 月に西ドイッ, ダルムシュタット 工科大学の交通計画・交通工学研究室で, 都市中心部の 買物交通の特性を調べるために実施されたものである. ダルムシュタット市 (人口 14 万人) 中心部の面的な歩 行者地区における主婦に対するアンケート調查の結果, 245 名, 1494 買物トリップ, 8955 リンクについての距 離データが得られた。 この地区はデパートが一軒あるほ かは, 小売店, 飲食店, 事務所などが集中する都心商店 街である.リンク長がガンマ分布に適合することを検証 するために目的地点が $j$ 点 $(j=1,2, \cdots, 12)$ あるトリ ップごとの第 $k$ リンク $(k=1,2, \cdots, j+1)$ のリンク長 分布についてカイ二乘検定による適合性検定を行う。こ のようにデータを分割する理由は, 特性の類似したデー タをまとめ, カイ二乗検定に適したサンプル数にデータ 数を減らすためである.

(2) 最小二乗法によるガンマ分布のあてはめ 
ここで, 頻度分布がヒストグラムとして与えられてい る確率変数の理論分布としてガンマ分布をあては就ると き，そのパラメーターを最小二乗法に基づいて推定する 方法を開発したのでそれについて述べる.

ガンマ分布の確率密度関数を, 式（6）のように表わ し, また, 階級の幅を $w$ とし, 第 $i$ 階級の頻度の比率 を $Y_{i}(i=1, \cdots, n)$ とするとき，

$$
y_{i}=\frac{Y_{i}}{w}
$$

とおく. $y_{i}$ は確率密度である. 第 $i$ 階級の確率変数 $x_{\boldsymbol{i}}$ に対する理論確率密度を $f_{i}\left(=f\left(x_{i}\right)\right)$ とし，

$$
G=\sum_{i=1}^{n}\left(f_{i}-y_{i}\right)^{2}
$$

を目的関数としてこれを最小とするようなパラメーター $\lambda$ および $k$ を求める。そのためには，式 $(9)$ を $\lambda, k$

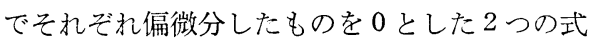

$$
\begin{aligned}
& F_{\lambda}=\Sigma\left(f_{i}-y_{i}\right) \frac{\partial f_{i}}{\partial \lambda}=0 \\
& F_{k}=\Sigma\left(f_{i}-y_{i}\right) \frac{\partial f_{i}}{\partial k}=0
\end{aligned}
$$

を連立方程式として解けばよい。

ここで, $f_{i}$ の $k$ による偏微分においてダイガンマ 関数

$$
r^{\prime}(k)=\frac{d}{d k} \ln \Gamma(k)=\frac{\Gamma^{\prime}(k)}{\Gamma(k)}
$$

を導入すると，級数展開による数值計算が可能になる. この連立方程式の解法にニュートン法を適用すると， ঋ(k)の $k$ による微分の項が現われるが，これはトラ イガンマ関数として級数展開ができ, 計算プログラムの 作成が容易になる．これらのことについては追録に補足 する。

計算はダルムシュタット工科大学の IBM $/ 370-168$, お よび科学警察研究所の パーソナルコンピュータ HP-85 により行った. 大型計算機では演算時間は $n$ が 20 程度 で約 2 秒, パーソナルコンピュータで約 10 分を要した.

c） パラメーターの值についての考察

この結果求的られた $k$ 值と $m$ 值をもつガンマ分布 の適合性は, カイ二乗確率を算出して比較することがで きる. 5 パーセントの有意水準を定めて, 適合性の検定 を行うと, 亲却されるものは目的地点数が 2 以上 10 以

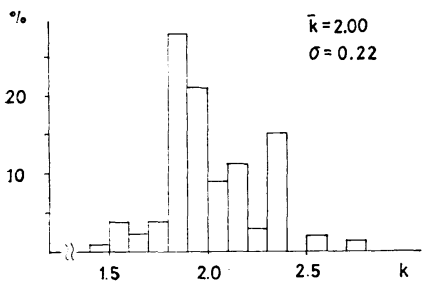

图-3 $k$ 值の分布
下のトリップにおけ

る,リングごとのデ ータ 63 のうち 12 で ある. 残りの有意な データ 51 につい, $k$ 值と $m$ 值に各デ ータのサンプル数で 重みをつけ，頻度分
布在求动ると図一 3 ，\%

4 のようになる.こ れらの分布の平均と 標準偏差は

$$
\begin{aligned}
& \bar{k}=2.00 \\
& \sigma_{k}=0.22 \\
& \bar{m}=190.0 \\
& \sigma_{m}=24.3
\end{aligned}
$$

となる.すなおち，

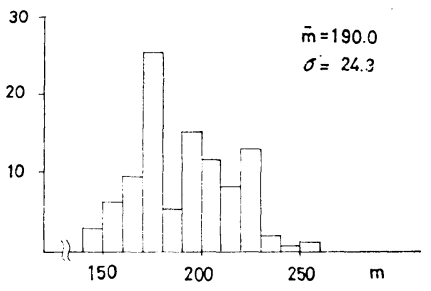

图一4 $m=k / 2$ の分布 $k=2, m=190$ とい う值のパラメーター をもつガンマ分布が リンク長分布の典型 的なものであること が知られる. 図一5 はパラメーターがこ れらの值に近く, カ イ二乗確率による適

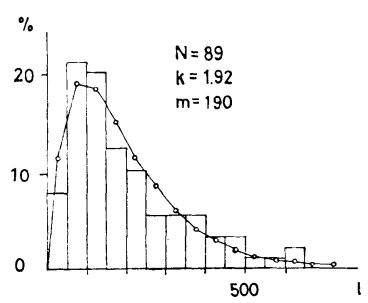

図一5 典型的なリンク長分布 (西ドイツ) 合度も高いデータである。

$k$ が 2 に等しいことは，式 (5) のただし書きより， $\alpha$ が 1, 寸なわち, 図一2の $f_{1}$ が直線となっていること を示している.すなわち潜在的な次の立寄地点が，リン ク始点からの距離に比例して分布していることを示すと 考えられる.このことはリンクの終点, すなわち次の立 寄地点（またはトリップ終点）となり得る商店や事務所 が，当該地区内でほぼ均等に分布していることを示すも のである.

$m$ 值は, 平均值の推定值である.リンク長の平均值は 目的地点の分布からも決まる值であることは, $m=k / \lambda$ の式にも示されている. この式の入の值は, 歩行に㧍 ける距離選好傾向を表わす式 (2) のパラメーターで, 式 (2) の平均值が $1 / \lambda$ となる. $1 / \lambda$ の值は, 調查対象 地域の歩行者が自由な距離選好のもとで歩行をしたとす れば, 平均的にどの程度まで歩くであろうかを示す值と 考えられる.この調查の場合 $1 / \lambda=190.0 / 2.00=95.0(\mathrm{~m})$ である.

入の值は歩行者の距離選好を示すパラメーターである が，個人に属するパラメーターといらよりは，むしろそ の歩行者が歩く都市の特性から決まるものと考えられ る.すなわち $\lambda$ 值は式 (5) により目的地点数の分布と 仮定する式のパラメーター $c$ と $\alpha$ (すなわち $k$ ) の関数 で, $k=2$ のとき, $\lambda=c$ である.

\section{（3） 歩行トリップ長の分布}

a) 立寄地点

図一1 に示したように, 1歩行トリップの中には, 1 か 所以上の立寄地点を含む. この立寄地点の数の分布はポ 


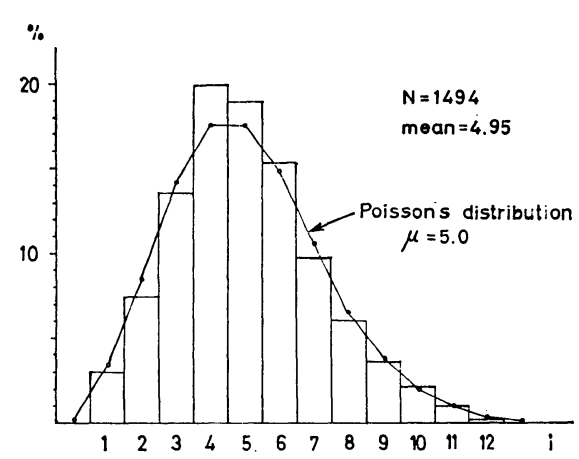

图一6 立奇地点数 $(j)$ の分布 (西ドイツ)

アソン分布に従うことが次のように導かれる. すなわ ち，一人の買物客が店舗を訪れる事象を $s$ とすると， 1 トリップで $j$ 店を訪れる確率は $s$ の生起確率 $p$ を パラメーターとする二項分布に従らが, $p$ はきわめて小 さく, をた, $N p=\mu(N$ は地区内の全店舗数, $\mu$ は平均 立寄店銿数）であるから，その分布形は

$$
P(j / \mu)=\frac{\mu^{j}}{j !} e^{-\mu} \text { (ポアソン分布) }
$$

となる. 図一6 は立寄店舗数の分布で, ポアソン分布に きわめてよく適合していることが示されている.

b）歩行トリップ長分布

トリップ内の立寄地点が $i$ か所ある歩行トリップのリ ンク数は $(i+1)$ である. 各リンク長は, 式 (6) で示さ れる確率密度関数をもつと仮定できるが, ガンマ分布の モーメント母関数は

$$
\varphi_{X}(t)=\frac{1}{\left(1-\frac{t}{\lambda}\right)^{k}}
$$

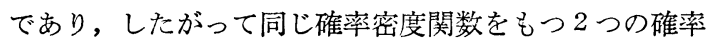
变数 $X, Y$ の和の確率密度関数のモーメント母関数は

$$
\varphi_{X+Y}=\varphi_{X} \varphi_{Y}=\frac{1}{\left(1-\frac{t}{\lambda}\right)^{2 k}}
$$

となり，再帰性を有することが示される ${ }^{12)}$. したがっ て, $i$ リンクをもつ歩行トリップ長 $x=\sum_{j=1}^{i} x_{j}\left(x_{j}\right.$ は第 $j$ リンクの長さ) の確率密度関数は再び次のよらなガン マ分布となる.

$$
f_{i}(x)=\frac{\lambda^{i k} x^{i k-1}}{\Gamma(i k)} e^{-\lambda x}
$$

ただし, $i:$ リク数, $x$ : 歩行トリップ長, $\lambda, k:$ 式 (6) のパラメーター

結局, 歩行トリップ長の分布 $g(x)$ は, 式 (15) を, リンク数の分布 (式 (12) の確率変数を $j=i-1$ と変換 した分布）で加重平均したもの，すなわち，

$$
g(x)=\sum_{i=1}^{\infty} \frac{\mu^{(i-1)}}{(i-1) !} e^{-\mu} \frac{\lambda^{i k} x^{i k-1}}{\Gamma(i k)} e^{-\lambda x}
$$

となることが導かれる.

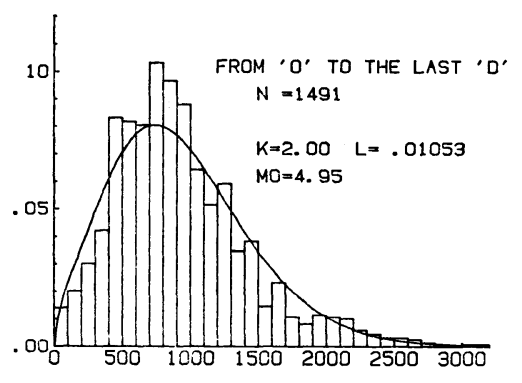

\section{図一7 始点から取終立奇地点までの距離分布 （西ドイツ）}

各パラメーターの值を $k=2, \lambda=k / m=0.01053, \mu=$ 4.95 として式（16）のグラフを描き，それを調查結果 から得られた歩行トリップにおける始点から最後の目的 地点までの歩行距離分布に重ねると図一7 が得られる。 この図にはトリップ長が $700 \mathrm{~m}$ から $1000 \mathrm{~m}$ のときに 仮定した頻度よりも観測された頻度が特に多いことが現 われているが，これはリンク長分布における $100 \mathrm{~m}$ か ら $150 \mathrm{~m}$ の階級值における頻度の突出傾向とも関連す ると考えられる.このことは, このデータに固有の特性 か, あるいは歩行距離の選好傾向として仮定する式が式 （2）のようでなく,さらにパラメーターを加えた他の表 現によるべきであることを示すものであるかについて は，今後の検討にゆだねたい。

なお, トリップ長全体を起点から終点までとせず, 起 点から最後の立寄地点までとして示したことは, 次の理 由による.すなわち, 最後の立寄地点から終点までの終 端リンク長分布には終点が始点と同じところである場合 と異なる場合とでは, パラメーターに大きな差がみられ る. 後者は $k=2.3, m=k / \lambda=184 \mathrm{~m}$ でリンク長分布と して通常の值とみなし得るが, 前者は $k=2.0, m=k / \lambda$ $=237 \mathrm{~m}$ であり, 通常のリンク長分布とは考えられな い.これは，始点へ戻る場合は拘束的な動きであるため に生じたことであると思われる.

\section{4. 横浜市中心部における歩行距離}

\section{(1) 概 要}

歩行距離に関する統計学的考察は, 西ドイッで得られ たデータに基づいて行ったが, 平均歩行距離や立奇地点 数は, その国の習慣, 都市の規模などに影響されると考 えられ,わが国における実態についても, 調査した。こ の章では横浜市の中心部で実施した歩行距離調査の結果 を示し， 3. で展開した 理論を適用するとともに, わが 国におけるパラメーターの值について考察を行う.

調査は昭和 52 年 5 月に横浜市中区の桜木町駅と関内 
駅周辺，および関内と伊勢佐木町の街頭の歩行者に対し て実施された．この地区は横浜市の中心業務地区，およ び旧来からの商業地区である. 調査の対象となった歩行 者は成人男女約 3000 名で, 地域内の鉄道駅, バス停留 所, 駐車場（パーキングメーターを含む）の周辺ですで に歩行トリップを終え，これらの施設から交通機関を利 用しようとする歩行者（たとえばバスに乗るためにバス を待つ人) に, 年踚, 歩行の目的, 歩行トリップ内容を 質問した. 調査対象から除外した者は, 通学目的の学生 と生徒, 対象地域内に目的地のない者, 交通機関の乗換 えのみを目的とする者, 調査対象区域内の交通施設を利 用しない歩行者，高龃と認められる者である.

歩行目的は, 通勤, 業務, 家事・買物, レジャー・レ クリエーション, その他とする. トリップ目的が複数あ る場合には，主たる 1 目的を記入した。

歩行トリップの内容は, 起点となる駅などの交通の結 節点から, 終点となる交通の結節点までの歩行径路と, 立寄地点を地図上に記入する方法で調べた. 始点, 終点 が大規模な施設（駅やデパートなど）である場合が多い ので，それらを，各施設の，公道に接する出入口とし た.

交通の結節点とは, 鉄道駅 (国鉄, 地下鉄), バス停留 所, 駐車場, パーキングメーター，タクシーの乗降地点， 送迎または自ら運転する自家用車の乗降地点である.

調査日は 19 日 (木), 20 日 (金), 22 日（土）の正 午から 18 時 30 分までであり, 天候は晴, および最りで あった. 調査員は街頭で以上の項目について質問し, 調 查票に記入した. 得られた有効サンプル数は 3351 件 で，うち平日分は 1851 件，休日分は 1500 件である. 通勤トリップと業務トリップはそれぞれ 784 件, およ び 579 件のデータが得られたが, うち平日分は 765 件 (95\%)，および 552 件 (95\%) であった. 家事・買物目 的と, レジャー・レクリエーション目的のトリップにつ いて得られた 1505 件, 483 件のうち, 休日分は 1058 件 $(70 \%), 396$ 件 $(82 \%)$ であった.

\section{（2）調査結果とその考察}

a) 立寄地点数

トリップ目的ごとの平均立寄地点数は業務 1.19 , 家 事・買物 1.54，レジャー・レクリエーション 1.37 であ, り，いずれも小さい值である. 家事・買物トリップにつ いて，立寄地点数の分布をみると図一8のようになっ ている.このような, 1 トリップにおける立寄地点数の 少なさ注，わが国の生活慣習に起因する歩行トリップの 特徵ということができるだろう．立寄地点が 1 か所のみ の買物トリップが圧倒的に多いことは，買物客が 1 回の トリップで訪れる店の数を確率変数とすることができな

いことでもあり， したがってポアソ ン分布にあてはめ ることもできな い.

b）リンク長の 一般的傾向

リンク長のデー タは 7029 リンク について得られ た.これを歩行目

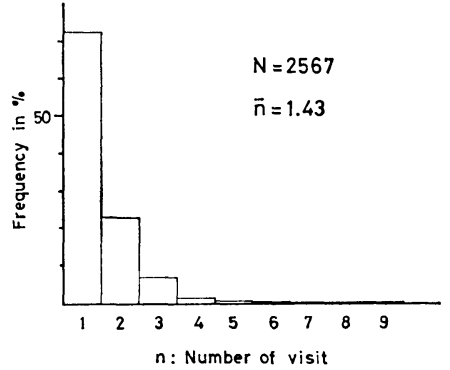

図一8 家事・買物トリップの立奇 地点数 (横浜)

的別に, 始端リンク（歩行トリップ開始地点から最初の 目的地まで）と，始・終端リンク以外のものについてみ ると, それぞれの平均值は表一3 のようになっている. この表から始・終端リンク以外のものは, $k$ が 1 に近 く, したがって歩行距離の選好傾向と仮定した分布形に 近いことが知られる（図一9）。このことは，第二以降の 目的地は，強い目的意 識があって訪れるとい うよりも,「ついでに」 訪れる傾向のほうが強 いことを示すものと考 えられる。これは，西 ドイツ・ダルムシュタ ットの主婦の都心商業 地区での買物トリップ

\section{表一3 歩行目的別平均リンク 長およひ $\boldsymbol{k}$ 值 (横浜)}

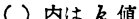

\begin{tabular}{|c|c|c|}
\hline 始 端 & リン ク & $\begin{array}{l}\text { 始・蔠端以 } \\
\text { 外のリンク }\end{array}$ \\
\hline 勤 & $497 \mathrm{~m}(1.9)$ & - \\
\hline 務 & $458 \mathrm{~m}(1.7)$ & $335 \mathrm{~m}(1.1)$ \\
\hline 物 & $430 \mathrm{~m}(2.2)$ & $210 \mathrm{~m}(0.7)$ \\
\hline レシ்ャー & $427 \mathrm{~m}(2.1)^{*}$ & $362 \mathrm{~m}(0.9)$ \\
\hline
\end{tabular}

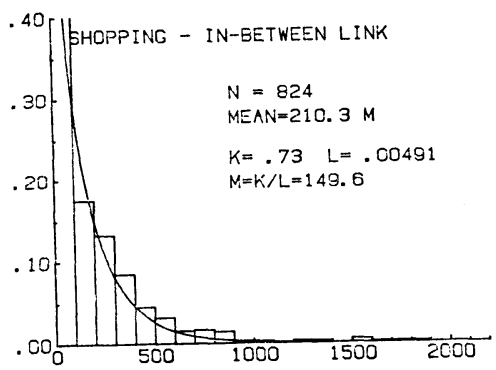

図一9家事・買物トリップの中途リンク 長分布 (横浜)

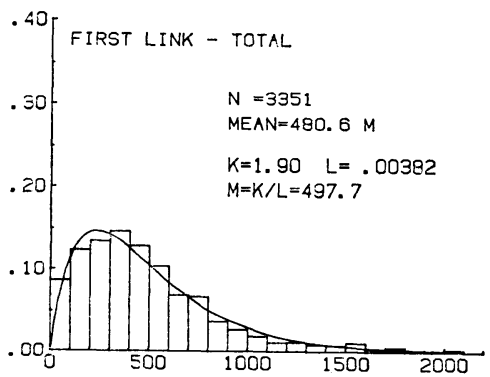

図一10 始端リンク長分布（横浜） 


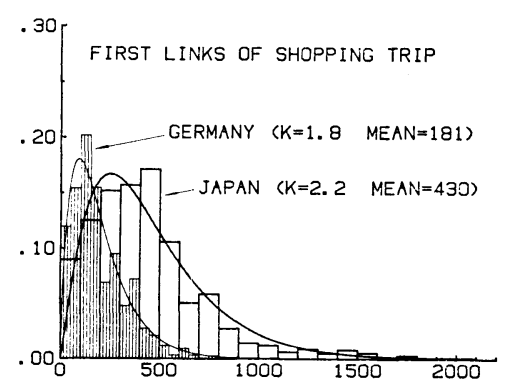

図一11家事・買物トリップの始端リンクの比較

の傾向と大きく異なる点である.

c）始端リンク

表一3にみるように，始端リンクの $k$ 值は $1.7 \sim 2.2$ であり，すでに述べたリンク長についての理論により説 明できる。始端りンク長分布は 図一10のと衫りであり， $k$ 值は $1.9, m=k / \lambda=498 \mathrm{~m}$ である.

買物トリップについての始端リンクを，西ドイッの同 様のデータと比較すると 図一11のようであり，平均歩 行距離の違いが明らかである. 式 (5) の $c$ 值は日本で $1.20 \times 10^{-3}$, 西ドイッで $23.7 \times 10^{-3}$ であり，目的地点の 分布の差が読み取れる.また, $、$ 值の逆数, すなわち自 由な距離選好のもとでの歩行における平均も $c$ 值の差か ら, 日本では $200 \mathrm{~m}$, 西ドイツでは $111 \mathrm{~m}$ となっている.

\section{5. おわりに}

この小論注都市内の歩行トリップ長に関する理論的考 察に主眼をおいた。そのため, 調査データの分析結果は そのごく一部を示したにとどまっているが，本研究にお ける結果をまとめると次のようになる。

（1）歩行トリップ長の頻度分布は自由な距離選好を 行うときに平均的に歩くであろう距離の逆数 $\lambda$, 潜在的 目的地点の地域的な分布の仕方を示すパラメーター $k$, トリップにおける平均立寄地点数 «をパラメーターと する式（16）で表わすことができる.

（2）歩行トリップは，リンクに分割したうえで，扱 うべきである。特に交通結節点を始点とする始端リンク 長の分布が，各交通施設の影響圈を説明する手がかりと なる。

（3） 買物トリップの始端リンク長分布は $k=2$ のガ ンマ分布となることは, 西ドイッ, 日本のいずれの調査 絬果からも導き出されたが, 中途のリンク長分布の $k$ 值 は西ドイッの場合, 約 2 であるが, 日本のデータからは 約1であることが算出された。これはそれぞれの国の生 活慣習による違いであり，日本の場合，二番目以降の立 寄地点は, むしろついでに立寄る傾向が強いことを示し ている.
（4）歩行における距離の選好を表わす関数, 式 (2) のパラメーター $\lambda$ は, 目的地の地域的広がりを示す関 数, 式 (1) の 2 つのパラメーターによって表わされる. したがって, 交通結節点の影響範囲を想定する場合, 都 市規模により，その基準值が異なることとなる。

（5） ガンマ分布のパラメーターの最小二乗法による 推定をパーソナルコンピューターで行う方法を開発した ので紹介する．今後はこの理論を交通施設の配置計画の 基礎として, あるいは人の歩行行動の分析の基礎として 適用し得るように発展させたいと考えている.

なお，この論文は参考文献 13),14）をもとに，新し い展開を行ったものである.

西ドイツに扝ける研究のご指導をいただいたダルムシ ユタット工科大学のレッコ教授ならびに同大学のフライ 研究員には末尾ながら心より謝意を表する次第である。

\section{付録一1}

ここでは非線形連立方程式 (9), (10) の解法について 述べる.これらの式はそれぞれ次のようになる。

$$
\begin{aligned}
& F_{\lambda}=\sum\left(f_{i}-y_{i}\right) \frac{\left(\lambda x_{i}\right)^{k-1}\left(k-\lambda x_{1}\right)}{\Gamma(k)} e^{-\lambda x_{i}} \\
& F_{k}=\sum\left(f_{i}-y_{i}\right) \frac{\lambda^{k} x_{i}{ }^{k-1}\left\{\ln \left(\lambda x_{i}\right)-\psi^{\prime}(k)\right\}}{\Gamma(k)} e^{-\lambda x_{i}}
\end{aligned}
$$

ただし， $\Gamma(k) ， \psi(k)$ は，それぞれガンマ関数，および ダイガンマ関数

これをニュートン法によって解く。このときに用いる 係数行列は次のとおりである.

$$
A_{l}=\left(\begin{array}{ll}
g_{\lambda \lambda} & g_{\lambda k} \\
g_{k \lambda} & g_{k k}
\end{array}\right)
$$

ただし，

$$
\begin{aligned}
& g_{\lambda \lambda}=\frac{\partial F_{\lambda}}{\partial \lambda}=\Sigma\left\{\left(\frac{\partial f_{i}}{\partial \lambda}\right)^{2}+\left(f_{i}-y_{i}\right) \frac{\partial^{2} f_{i}}{\partial \lambda^{2}}\right\} \\
& g_{\lambda k}=\frac{\partial F_{\lambda}}{\partial k}=\Sigma\left\{\frac{\partial f_{i}}{\partial \lambda} \cdot \frac{\partial f_{i}}{\partial k}+\left(f_{i}-y_{i}\right) \frac{\partial^{2} f_{i}}{\partial \lambda \partial k}\right\} \\
& g_{k \lambda}=\frac{\partial F_{k}}{\partial \lambda}=g_{\lambda k} \\
& g_{k k}=\frac{\partial F_{k}}{\partial k}=\Sigma\left\{\left(\frac{\partial f_{i}}{\partial k}\right)^{2}+\left(f_{i}-y_{i}\right) \frac{\partial^{2} f_{i}}{\partial k^{2}}\right\}
\end{aligned}
$$

ここで,

$$
\begin{aligned}
\frac{\partial^{2} f_{i}}{\partial \lambda^{2}}= & \frac{\lambda^{k-2} x_{i}{ }^{k-1}\left\{\left(k-\lambda x_{i}\right)^{2}-k\right\}}{\Gamma(k)} e^{-\lambda x_{i}} \\
\frac{\partial^{2} f_{i}}{\partial \lambda \partial k}= & \frac{\lambda^{k-1} x_{i}{ }^{k-1}\left[\left(k-\lambda x_{i}\right)\right.}{\Gamma(k)} * \\
& * \frac{\left.\left\{\ln \left(\lambda x_{i}\right)-\psi(k)\right\}+1\right]}{\partial k^{2}} e^{-\lambda x_{i}} \\
\frac{\partial^{2} f_{i}}{\partial k^{2}}= & \frac{\lambda^{k} x_{i}^{k-1}\left[\left\{\ln \left(\lambda x_{i}\right)-\psi(k)\right\}^{2}-\psi^{\prime}(k)\right]}{\Gamma(k)} e^{-\lambda x_{i}}
\end{aligned}
$$

ただし $\psi^{\prime \prime}(k)=\frac{d}{d k} \psi^{\prime}(k)$ (トライガンマ関数) 


$$
\text { 表一4 } \quad C_{j}\left(1 / \Gamma(x)=\sum_{j=1}^{26} C_{j} x^{j}\right)^{15)}
$$

\begin{tabular}{r|r||c|r}
\hline$j$ & $C_{j}$ & $j$ & \multicolumn{1}{c}{$C_{j}$} \\
\hline 1 & 1.0000000000000000 & 14 & 0.0000011330272320 \\
2 & 0.5772156649015329 & 15 & -0.0000002056338417 \\
3 & -0.6558780715202538 & 16 & 0.0000000061160950 \\
4 & -0.0420026350340952 & 17 & 0.0000000050020075 \\
5 & 0.1665386113822915 & 18 & -0.0000000011812746 \\
6 & -0.0421977345555443 & 19 & 0.0000000001043427 \\
7 & -0.0096219715278770 & 20 & 0.0000000000077823 \\
8 & 0.0072189432466630 & 21 & -0.0000000000036968 \\
9 & -0.0011651675918591 & 22 & 0.0000000000005100 \\
10 & -0.0002152416741149 & 23 & -0.0000000000000206 \\
11 & 0.0001280502823882 & 24 & -0.0000000000000054 \\
12 & -0.0000201348547807 & 25 & 0.0000000000000014 \\
13 & -0.0000012504934821 & 26 & 0.0000000000000001 \\
\hline
\end{tabular}

\section{ガンマ関数 $\Gamma(x)$ の計算法}

(1) $x$ が整数の場合

$$
\begin{aligned}
& \Gamma(1)=1 \\
& \Gamma(x)=(x-1) !(x \geqq 2)
\end{aligned}
$$

(2) $0<x<1$ の場合

$$
h(x)=\frac{1}{\Gamma(x)}=\sum_{j=1}^{\infty} C_{j} x^{j}
$$

より算出する. $C_{j}$ の值は 表一4 に示す.

(3) $x>1$ (整数以外) の場合

$$
\begin{aligned}
& n=[x], z=x-n \text { として } \\
& \Gamma(x)=(n-1+z)(n-2+z) \cdots(1+z) \cdot z \cdot \Gamma(z)
\end{aligned}
$$

より算出する. $\Gamma(z)$ の值は上記 (1)より求める.

ダイガンマ関数

(1) $x$ が整数の場合

$$
\begin{aligned}
& \psi(1)=-r \\
& \psi(x)=-r+\sum_{j=1}^{x-1} \frac{1}{j}(x \geqq 2)
\end{aligned}
$$

ただし， $r=0.577215665$ (オイラーの定数)

(2) $0<x<1$ の場合

$$
\begin{aligned}
\psi(x) & =-\left\{\frac{1}{\Gamma(x)}\right\}^{\prime} \cdot \Gamma(x)=-\frac{h^{\prime}(x)}{h(x)} \\
& =-\frac{\sum j C_{j} x^{j-1}}{\sum C_{j} x^{j}}
\end{aligned}
$$

\section{より算出する.}

(3) $x>1$ (整数以外) の場合 $n=[x], z=x-n$ として

$$
\begin{aligned}
\psi(x)= & \frac{1}{(n-1)+z}+\frac{1}{(n-2)+z}+\cdots \\
& +\frac{1}{1+z}+\frac{1}{z}+\psi(z)
\end{aligned}
$$

より算出する. $\psi(z)$ は上記 (2) より求める.

トライガンマ関数 $\psi^{\prime}(x)$ の計算法

(1) $x$ の整数の場合

$$
\psi^{\prime}(1)=\xi(2)=\sum_{j=1}^{\infty} \frac{1}{j^{2}}=\frac{\pi^{2}}{6}
$$

$$
\begin{aligned}
\psi^{\prime}(x)= & \xi(2)-1-\frac{1}{2^{2}}-\frac{1}{3^{2}}-\cdots \cdots \\
& -\frac{1}{(x-1)^{2}}(x \geqq 2)
\end{aligned}
$$

(2) $0<x<1$ の場合

$$
\begin{aligned}
& \psi^{\prime}(x)=\frac{\left\{h^{\prime}(x)\right\}^{2}-h(x) h^{\prime \prime}(x)}{\{h(x)\}^{2}} \\
& =\frac{\left\{\sum_{j=2}^{\infty} j C_{j} x^{j-1}\right\}^{2}-\left\{\Sigma C_{j} x^{j}\right\}}{\left\{\Sigma C_{j} x^{j}\right\}^{2}} * \\
& \text { * }\left\{\sum_{j=3}^{\infty} j(j-1) C_{j} x^{j-2}\right\}
\end{aligned}
$$

より算出する.

(3) $x>1$ (整数以外) の場合

$$
\begin{aligned}
n=[x], z= & x-n \text { として } \\
\psi^{\prime}(x)= & \psi^{\prime}(z)-\frac{1}{z^{2}}-\frac{1}{(z+1)^{2}}-\cdots \\
& -\frac{1}{(z+n-1)^{2}}
\end{aligned}
$$

より算出する・ 行 (z) は上記 (2) より算出する.

\section{付録一2}

歩行トリップ長に関するさまざまな考え方については 参考文献 16) の pp. 217〜223 に記されている. 特に 式（2）が「出発地から一定の距離を離れるごとに, 単 位距離につき,一定の割合で行動がストップすること」 を仮定した個人の行動圏モデルであることがこの文献に より裏付けられている.

\section{参考 文 献}

1）交通工学研究会：住宅地等における 自動車利用の実態に 関する調查報告書, 昭和 43 年.

2) Lennson, H.S. : Urban Travel Characteristics, Transportation and Traffic Handbook, 1976.

3) Pushkarev, B. and J.M. Zupan : Pedestrian Travel Demand, Highway Research Record, No. 355, 1971.

4) "Parking" 1957, ENO Foundation.

5) Rutherford, G.S. and J.L. Schofer : Analysis of Some Characteristics of Pedestrian Travel, Transportation Research Record, No. 605, 1976.

6) Pieper, F. : Grundlagen für die Planung von Fußgängerbereichen und Parkbauten in Innenstädten, Haus der Technik, 109, 1967.

7) Monheim, R. : Fußgängerbereiche in deutschen Städten, Institut für Raumordnung Information, 23. Jg. Nr. 2, 1973.

8) Goudappel, H.M. and IP.B. von Gurp : Dutch Town Centers, Street for People, OECD, 1974.

9) Walther, K.: Die Fußweglänge zur Haltestelle als Attrativitäts-Kriterium im öffentlichen Personennahverkehr, Verkehr und Technik, 26. Jg. Heft 10, 11, 1973.

10) Verkehrsraum Düsseldorf, Oberbaudirektor der Landeshauptstadt Düsseldorf, 1973. 
11) Gasperini, A. : Rouen, France, Street for people, OECD, 1974 .

12）藤本 熙: 統計数理の基礎と応用, 日刊工業新聞社, p. 104, 昭和 43 年.

13）村田隆裕：買物交通の歩行距離, 科警研報告, 交通編, 18 巻 1 号, 1977.

14）村田隆裕 : 都市中心部における 歩行距離, 移警研報告,
交通編, 19 巻 1 号, 1978.

15) Abramowitz, M. and I.A. Stegun : Handbook of Mathematical Functions. Dover Press, Inc., N.Y., pp. 256 260, 1972.

16）岡田光正ほか：建築と都市の人間工学, 鹿島出版会, pp. $217 \sim 223,1977$. 